\title{
Perception and Interest of English Language Learners (ELL) toward Collaborative Teaching; Evaluation towards Group Activities
}

\author{
Abdulbagi Babiker Ali Abulhassan ${ }^{1} \&$ Fatima Ibrahim Eltayeb Hamid $^{1}$ \\ ${ }^{1}$ English Department, University College in Addair, Jazan University, K.S.A \\ Correspondence: Abdulbagi Babiker Ali Abulhassan, English Department, University College in Addair, Jazan \\ University, K.S.A.
}

Received: March 2, 2021

Accepted: March 29, 2021

Online Published: April 1, 2021

doi: 10.5539/elt.v14n5p1

URL: https://doi.org/10.5539/elt.v14n5p1

\begin{abstract}
This study focuses on evaluating the perceptions of Saudi ELLs enrolled in secondary classes, with an emphasis on group activities. A total of 424 ELLs were enrolled in this study on the basis of purposive sampling technique from eight public schools in Riyadh city, Saudi Arabia during the time period of January 2020 to May 2020. A close-ended questionnaire comprising 23 items was distributed online to collect data regarding perceptions of participants towards collaborative teaching and group activities. Descriptive statistics, independent t-test and One-Way ANOVA were used as statistical tools to analyze the data through SPSS version 25.0. Collaborative teaching techniques and group activities were preferred by ELLs with respect to gender differences and grade-level differences, respectively. It was concluded that students studying in different classes preferred group activities in comparison with collaborative teaching techniques.
\end{abstract}

Keywords: collaborative teaching, English language learners, group activities, perceptions, Saudi Arabia

\section{Introduction}

Collaborative learning refers to learning that is based on social activities which simulates participants' active involvement in their learning activities (Lee, 2014). It is further defined as an educational approach of teaching and learning that involves groups of learners working mutually to create a product, solve a problem or complete a task (Stead, 2018). Collaborative learning activities are based on pair and group work and postulate that a class that interacts in cooperative learning involves students working in groups or pairs to successfully achieve their learning objectives (Ebru, 2018).

Group activities are considered as strategies used in both cooperative and collaborative learning, in which learners are involved as co-learners and includes all sorts of learning ranging from collaborative and cooperative group activities to peer tutoring (Chen, 2018). According to Marks and O'Connor (2013), group activities work as a type of cooperative learning: a technique that involves collaborative working. In addition, group activities are defined as activities in which learners work mutually as a team or group either for producing a certain product or achieving a fundamental objective (Su et al., 2018).

The collaboration and exchange of ideas between two or more people is associated with the language learning, and this can be achieved through classroom group activities (Such, 2019). Since the association between group activities and language acquisition is consistent, the qualities that English language learners (ELLs) acquire from participating in group activities help them in learning the language more effectively. This makes most of the parents and teachers notably concerned regarding the ELLs' acquisition of the language which is merely taught to them via speaking, reading, and writing tasks that are individually practiced (Takeuchi, 2016). ELLs require the social engagement via group activities so that they can converse with others about what they listen and know how their peers speak in English, even though individual work such as, writing out the same words in their notebooks helps them to concentrate on their work and its practice (Poupore, 2016). Every school has ELLs, where learners are generally in the classrooms. This makes it important to pinpoint that teachers need to apply the pedagogy of group activities to develop opportunities for students which ultimately encourage them to engage and communicate with their peers. This teaching strategy is equally important even in schools that have lower extent of ELLs (Hendy, 2020).

ELLs' perspectives towards group activities and the ways they utilize group activities assist them in developing 
and improving their language and overall learning skills (Poupore, 2018). Previous researches on collaborative teaching emphasized its effects on academic achievements of elementary, secondary, high school and university students (Batdi, 2013; Çokparlamış, 2010; Kartal et al., 2018; Tonbul, 2006). While very few of these studies examined teachers' or learners' perceptions of collaborative learning (Batdi, 2013; Gillies \& Boyle, 2011; Gillies $\&$ Boyle, 2010). Among them, some researchers have emphasized the perceptions of collaborative learning of young learners (Lee \& Macaro, 2013) whereas other studies have emphasized the perceptions of collaborative learning of secondary or high school learners (Lee \& Macaro, 2013). Previously, perceptions of male students of 10th grade were examined by Alghamdi and Gillies (2013), while, research has also been done on the perceptions of collaborative learning of adult learners (Lee \& Macaro, 2013; Sarobol, 2012; Tian \& Macaro, 2012). This study, however, emphasizes the perceptions of Saudi ELLs enrolled in secondary classes, on group activities. Additionally, the emphasis of this study is to extend the data collected by the questionnaires in order to offer a comprehensive perspective of the ELLs towards collaborative teaching and group activities. Following research questions were formulated:

Question 1: What are the perspectives of Saudi ELLs towards collaborative teaching?

Question 2: What are the perspectives of Saudi ELLs towards group activities?

Question 3: Is there any difference between the interest and perception of ELLs studying in different grades with respect to group activities and collaborative teaching?

\section{Literature Review}

\subsection{Theoretical Framework}

Collaborative learning is generally effective as it stimulates collaboration among learners and elevates classroom engagement. Sociocultural Theory proposed by Vygotsky (1978) postulates that social engagement among learners enhances language development and learning happens through collaboration and interaction. Likewise, Vygotsky (1978) recommends that teachers should do more than just organizing the environment to help learners discover things on their own. This notion refers back to the proximal development zone of Vygotsky in which the individual is not successful to solve a problem but rather solves and accomplishes it under the guidance of an adult.

According to Woolfolk (1998), learners should be guided through opportunities, explanations, or demonstrations for collaborative learning. It is argued that language proficiency is developed in language learners when they engage and cooperate with more advanced learners. Thereby, teachers should utilize group activities that contribute in creating a stimulating environment in which learners can use the target language in collaborative learning and help them to receive the social support they require throughout their language development. Likewise, learning can be effectively facilitated through pair activities, group activities, and role playing (Tao \& Gunstone, 1999).

\subsection{Literature Review}

\subsubsection{Collaborative Teaching}

Since the late 1980s, collaborative learning has been in practice in majority of the classrooms. It involves not only grouping learners to work together, but also incorporating significant aspects such as shared meaning and negotiation (Le, Janssen, \& Wubbels, 2018). Group activities improve the learning process as it occurs socially. One of the outcomes of collaborative learning is that learners actively engage with each other which will encourage the elaboration of conceptual knowledge via collaborative teaching (Chen, 2018). This shows that a more vivid demonstration can be drawn as an outcome of social engagement between the students. In addition, it is an effective approach for preventing the teachers from providing additional information or answers to the learners and for offering self-reasoning opportunities to them by asking questions (Pathak \& Intratat, 2016).

The collaborative teaching approach has been incorporated in several ways in the existing technologically advanced era. Computer-supported collaborative teaching is amongst one of the ways used in higher education which marks a paradigm shift from the conventional face-to-face group activities (Law et al., 2017). Collaborative teaching is also utilized in a distance education course that is developed and taught in a virtual learning environment. It is also witnessed that collaborative teaching will enhance the study and learning of the subject matter, boost a positive attitude and social engagement along with an increase in the interest of the students in the subject matter (Carstensen et al., 2020). Previously, studies have indicated that learners will learn effectively when the learning process is done in a social yet educational approach. This is because the understanding level of students is improved through active learning and this approach, therefore, leads to improved learning outcomes (Krammer et al., 2018; Park \& Ham, 2016). It is essential that the teacher should 
construct a non-threatening and conducive classroom environment that will evoke and maintain the willingness of learners. The collaborative teaching method can foster a non-threatening environment. In such an environment, the learners will not be under pressure and they will be willing to engage themselves in discussions. According to Seng (2006), collaborative teaching will expand the likelihood of academic success. It is also observed that the learners enjoy working in groups when interesting collaborative activities are conducted in the classroom. Therefore, it makes sense to adopt a learning method that will enable and not obstruct the learning process of the students.

Collaboration also refers to practice in a safe environment, which is made up of a diverse group of individuals who have a mutual interest or issue resulting in exploring the potential solutions for the predefined tasks (Novitasari, Raja, \& Flora, 2018). English language learners are confronted with opportunities to improve their oral skills when they experience conflict on tasks and objectives, while working collaboratively. Collaborative teaching help students to create opportunities so that they can expose themselves to second language learning environment and express their opinions; it also assists them to enhance their classroom participation. This is specifically favorable for students that are reluctant to participate in classroom discussions, either due to lack of confidence or shy nature (Chen \& Yu, 2019). Students' learning outcomes are enhanced when learning and teaching are collaborative and reflective. The engagement of students and teachers in dialogue is mandatory as it allows them to examine themes to equalize and create new understanding of the world collaboratively (Harper, Lamb, \& Buffington, 2019).

In collaborative learning, teachers are facilitated through real-life material to identify and address students' needs, indirectly such as routine assessment and reflect on collaboration between the teachers and learners by observing students' performances in the classroom (Murdoch, Epp, \& Vinek, 2017). Students can get practical benefit from the development of new knowledge when teachers have the eagerness and autonomy to practice novel strategies with respect to learning materials and activities in the language classrooms. Therefore, students learning collaboratively will experience successful and lively learning process and in particular, teachers can produce students with strong academic performance via collaborative learning.

According to Bailey, Almusharraf \& Hatcher (2020), the effort of instructor is important to promote and create online room that enables space to create and stimulate student responsibility in tasks triggering motivation. The characteristic nature of learning environments surrounded by individual teaching styles ignores any actual claims that forecasts course satisfaction based on intrinsic motivation for writing practice. Similarly, Novitasari (2019) was of the view that the role of English teachers is very essential and they must help the learners whenever they ask for assistance. In addition, they have to help facilitators as compared to instructors. The teachers have to manage the progress of their groups and further motivate all the group members for encompassing in the predefined tasks at each and every stage. Rao (2019) indicated that the predefined tasks will be finished easily in a fun-filled and learner-friendly environment when the learners do their tasks by sharing their responsibilities. Precisely, it was claimed that collaborative learning brought positive impacts for the learners. They worked collaboratively for solving issues, for achieving significant feedbacks, and for triggering confidence, which allowed to additional opportunities to seek practice.

In particular, the presence of their collaborative friends and assistance from the supervisor boosted their confidence for speaking (Novitasari, 2019). Additionally, there is an essential effect of interactivity with peers, online knowledge sharing behavior, and teachers on engagement of students, which significantly influence on academic performance of students (Ansari \& Khan, 2020). Collaborative method is beneficial in the advancements of students' competence and constructs a healthy learning environment in the classroom. The results indicated the enhancement noted while using collaborative learning activity in order to improve students speaking performance. According to Kamala \& Aziz (2020), students further provided positive feedback when this was completed than it was done individually.

\subsubsection{Group Activities}

Group activities allow students to foster their communication with each other as they learn from each other. ELLs require opportunities of language practice with English proficient students for improving their language skills. Through group activities, learners are able to eagerly participate in discussions and to freely interact in the classroom (Su et al., 2018). In group activities, students can also practice their oral language skills effectively as compared to a whole-class setting or with the teacher. Learners working together in a group have more learning opportunities in comparison with individual learning (Takeuchi, 2016). For instance, previous studies have incorporated a type of group activity called, 'think, pair, and share' that involves discussion between a pair of students before engaging in a whole class discussion (Schwartz \& Pollishuke, 2012; Bennett, Rolheiser, \& 
Stevahn, 1991; Kagan, 1990).

This assists students to express their thinking with a peer partner before engaging in the large group discussion and works efficiently to encourage those hesitant learners for rehearsing before speaking. Additionally, Cheong (2010) stated that novice peer is more likely to independently express his or her perspectives and ask questions to his or her peer as compared to his or her teacher, when two learners are grouped mutually with one being more competent as compared to the other. Evidence has also supported that learners benefit from peer tutoring process by constructing leadership and social skills, improving their own understanding of concepts and feeling a sense of achievement after explaining them to someone else (Marks \& O'Connor, 2013). According to Helfrich and Bosch (2011), pairing two ELLs will benefit both students equally through observations of self-expression. However, the pairing should be done by including a student with good English language competence in comparison with the second student. This indicates that ELLs can benefit from participating in group activities and have opportunities for improving their oral language skills.

One of the greater advantages of incorporating group activity in the classroom is that learners have the likelihood of communicating and engaging with each other. Engagement is essential for ELLs to learn the English language (Chen, 2018). ELLs can listen and have discussions with their peers when they are allowed to interact with other students in the classroom. Learners can develop discussions amongst themselves regarding the issue or topic being discussed with restricted interruptions by the teacher throughout the group activities. This makes learners competent enough for meaningful collaborations, while providing them the opportunities to exchange thoughts, feelings and ideas by participating in group activities (Ebru, 2018). Thereby, student interactions are stimulated and fostered that help them to develop and practice their social skills throughout the group work.

Student interaction and engagement is particularly essential for ELLs as it is one of the approaches in which ELLs obtain the English language through their surroundings and the engagement with other students (Stead, 2018). However, the challenge is that ELLs are not provided sufficient amount of time to practice their oral language skills (Lee, 2014). This is amongst the major issues because ELLs require opportunities to have conversations and utilize the language with peers that are proficient in English language to develop and enhance their communicative skills. Group activities naturally develop the classroom environment for student engagement and help ELLs to have chances to learn the language by observing their peers (Daba, Ejersa, \& Aliyi, 2017). Additionally, peer interactions may develop additional peer relationships between ELLs and non-ELLs, which are essential for ELLs to learn attitudes, cultural skills and values and develop social skills. Previous research has shown that ELLs feel less pressure for efficient working in groups (Babiker, 2018).

Role of peer interaction is thus critical and serves as a fundamental aspect of second language acquisition, as it facilitates students in learning and participation throughout various language learning activities. It is evident that via group activities, ELLs are offered opportunities to get involved in social conversations and interactions that improve their oral language skills through group activities.

\section{Methods}

A descriptive, correlational study design was used to determine the interest and perceptions of ELLs toward collaborative teaching with the implementation of group activities in a classroom setting. This study was conducted in Riyadh, one of the major cities of Saudi Arabia. Precisely, ELLs enrolled in grades 6 to 8 in the secondary schools were the target population of this study. Due to novel Coronavirus pandemic, researcher was unable to cover other cities in the country and reached out to those schools with personal reference. The data was collected in a period of 5 months from January 2020 to May 2020 and total eight state schools were covered.

The data were gathered after the learners completed four meetings. Collaborative speaking activities used in this research include group discussions to comprehend on a specific concern, group games, and shared-tasks like sorting and matching, role play, debate, and making a small project. Group performance was the example of the procedures of collaborative speaking activity. The class was divided into different groups. Two or three students were comprised within each group and then were asked for watching a short video. Each group was asked for formulating the issues on the basis of the video they watched after watching the video. Each member of the group has to offer one issue. Afterwards, each group was allocated to discuss and to bring solutions for every problem provided. Each group had to share the outcomes of the discussion after the discussed ended.

To calculate the sample size and include ELLs in the research, Raosoft Inc. calculator was used as one of the powerful survey tools for quantitative papers. Based on 5\% margin of error, $95 \%$ confidence level, unknown population size and 50\% response rate, the recommended sample size was 377 (Figure 1). In this regard, total 700 questionnaires were distributed to ELLs by their English teachers while delivering lectures through a virtual setting. The objective and rationale for their participation was recorded in an audio message which was shared 
with them before asking them to fill out the questionnaire. Parents of the interested participants were also informed regarding their participation. After providing complete guidance and information about the survey, ELLs were given a time period of 7 days to complete the questionnaire and return it back on the same link to their English teacher. Permission had already been taken from the heads of the schools and a copy of study's objective, informed consent form and questionnaire was provided to them so that they shall be aware of the questions asked from the students.

Total 439 questionnaires were received completely from ELLs with signed informed consent forms out of which 15 questionnaires were partially or incompletely filled by the participants. These questionnaires were excluded from the final sample size, which means 424 ELLs were the part of this study, yielding a response rate of $60.57 \%$.

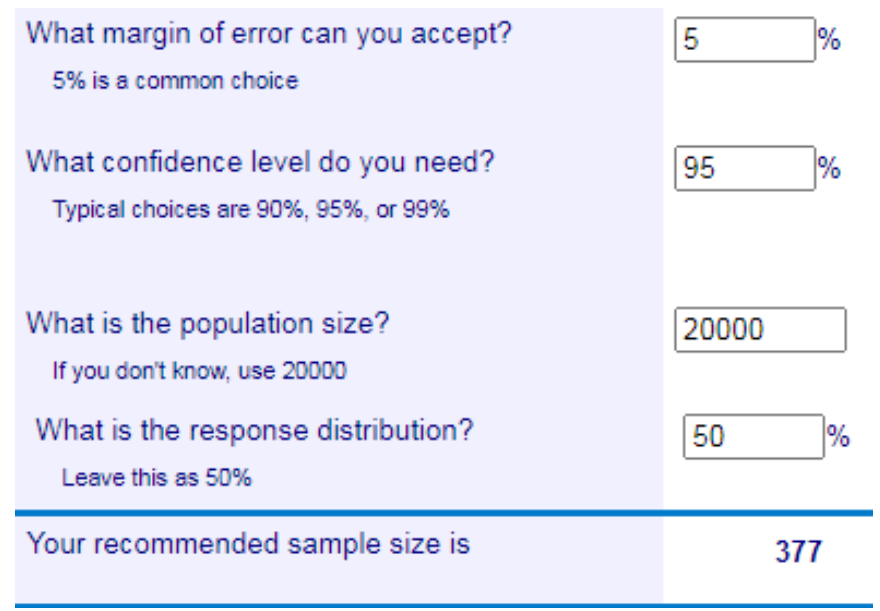

Figure 1. Sample Size Calculation

A close-ended questionnaire was prepared covering information related to ELLs 'demographics (age, gender, grades, etc.) and questions related to their perceptions toward collaborative teaching and group activities. Section $\mathrm{B}$ of the questionnaire covered questions related to collaborative teaching based on 11 items. These items were adopted from Babiker (2018). This section of the questionnaire was measured using multiple-choice-response scale. Section $\mathrm{C}$ of the questionnaire covered questions related to group activities based on 14 items. These items were adopted from Daba, Ejersa \& Aliyi (2017) and were measured using five-point Likert scale.

One of the assumptions of reliability assessment when using Cronbach's Alpha Coefficient is that the items should be in the form of statement so that the use of measurement scale can be considered valid for such statements. In this regard, items presented in Section B were modified in the form of statements as originally, they were presented as questions by Babiker (2018). After applying Cronbach's Alpha Coefficient for reliability assessment of the both sections ( $80 \%$ for collaborative teaching and $72 \%$ for group activities), it was observed that all the items of the questionnaire were valid enough to be proceeded in the final analysis. The questionnaire was validated from one of the fellow colleagues of the English department of King Saud University. Certain changes such as transforming questions to statements were recommended to make questionnaire useful for the analysis.

Statistical Package for Social Sciences (SPSS) version 25.0 was used to analyze the data collected in tabular representation. Descriptive statistics including mean and standard deviation (SD) were used for summarizing mean values of the items of Section B and C. Frequencies and percentages were used for presenting demographics of ELLs. Based on the correlational nature of this study, cross-tabulation or contingency tables were applied to analyze the relationship between categorical variables. The items in Sections B and C were presented categorically and analyzed with respect to both male and female ELLs. Independent sample t-test and One-Way ANOVA were used to determine the difference between interest and perception of ELLs towards group activities and collaborative learning with respect to their grades.

\section{Results}

Four hundred and twenty-four ELLs took part in this study. Out of 424 participants, $42.5 \%$ of them were $10-11$ years old, $60.4 \%$ were males, and $36.3 \%$ were in 8 th grade (Table 1). Means and standard deviation for collaborative teaching are summarized in Table 2. Based on the findings, the highest mean was recorded for the item "I like teacher to explain everything" $(\mathrm{m}=3.70)$, followed by "There is a positive influence of collaborative 
teaching on student's performance" $(\mathrm{m}=3.69)$, "Interacting in groups help producing fluent and accurate utterances" ( $m=3.69)$, and "I like to prefer talking in English" $(\mathrm{m}=3.69)$. Item "Course books provide enough material for group and pair work" recorded lowest mean score $(\mathrm{m}=3.59)$.

Similarly, mean scores for group activities are summarized in Table 3. The highest mean scores were recorded for the following items: "It helps me develop thinking ability and self-expression" $(\mathrm{m}=3.80)$, "A group grade is not fair" $(\mathrm{m}=3.72)$, "Group assignment makes me busy" $(\mathrm{m}=3.71)$, and "It gives me chance to share ideas with others" $(\mathrm{m}=3.70)$.

Table 1. ELLs Profile

\begin{tabular}{llll}
\hline Variables & Items & Frequency & Percentage \\
\hline Age & & & \\
& 10-11 years & 180 & 42.5 \\
& 12-13 years & 76 & 17.9 \\
& 14-15 years & 168 & 39.6 \\
Gender & & & \\
& Male & 256 & 60.4 \\
& Female & 168 & 39.6 \\
Grade & & & \\
& 6th grade & 151 & 35.6 \\
& 7th grade & 119 & 28.1 \\
& 8th grade & 154 & 36.3 \\
\hline
\end{tabular}

Table 2. Means and Standard Deviations for Collaborative Teaching

\begin{tabular}{lllll}
\hline Collaborative teaching & $\mathrm{N}$ & Mean & Std. Deviation \\
\hline $\begin{array}{l}\text { There is a positive influence of collaborative teaching on student's } \\
\text { performance }\end{array}$ & 424 & 3.69 & .934 \\
Teachers routinely use collaborative teaching techniques & 424 & 3.65 & .956 \\
Group discussions and activities help in fostering students' & 424 & 3.66 & .972 \\
communication & & & \\
Interacting in groups help producing fluent and accurate utterances & 424 & 3.69 & .954 \\
Course books provide enough material for group and pair work & 424 & 3.59 & .973 \\
I enjoy working and learning in groups & 424 & 3.67 & .907 \\
I like teacher to explain everything & 424 & 3.70 & .906 \\
I like to learn conversation & 424 & 3.62 & .902 \\
I like to prefer talking in English & 424 & 3.69 & .967 \\
I like that teachers give problems to work on & 424 & 3.64 & .967 \\
Teachers use modern and progressive methods to teach English & 424 & 3.65 & .966
\end{tabular}
Table 3. Means and Standard Deviations for Group Activities

\begin{tabular}{llll}
\hline & $\mathrm{N}$ & Mean & Std. Deviation \\
\hline I prefer group work than other types of assessment & 424 & 3.65 & .965 \\
It motivates me to learn from work & 424 & 3.66 & .911 \\
It develops my independent learning habit & 424 & 3.67 & .934 \\
It helps me develop thinking ability and self-expression & 424 & 3.80 & .958 \\
It gives me chance to share ideas with others & 424 & 3.70 & .907 \\
I learn better from group interaction than lecture & 424 & 3.68 & .894 \\
A group grade is not fair & 424 & 3.72 & .922 \\
Group assignment makes me busy & 424 & 3.71 & .976 \\
It adds burden work on me & 424 & 3.65 & .999 \\
It is difficult to get together outside class & 424 & 3.66 & .950 \\
It is difficult to get relevant references & 424 & 3.65 & .923 \\
It is difficult to share members work equally & 424 & 3.69 & .928 \\
\hline
\end{tabular}


Perception of ELLs toward collaborative teaching and group activities are presented in Tables 4 and 5 respectively. Based on the participants' perceptions, "I like to learn conversation" $(42.5 \%)$, "I like teacher to explain everything" (41.7\%), "I enjoy working and learning in groups" (41.3\%) and "Group discussions and activities help in fostering students' communication" (37.7\%) were the items that stimulated them towards collaborative teaching.

Similarly, "It gives me chance to share ideas with others" (3.70\%), "A group grade is not fair" $(42.7 \%)$, "It motivates me to learn from work" $(42.0 \%)$, and "It is difficult to share members work equally" (3.69\%) were the reasons that motivated them to learn and develop English language in group activities.

Table 4. ELLs Perception on Collaborative Teaching

\begin{tabular}{llllll}
\hline Collaborative teaching & $\begin{array}{l}\text { Strongly } \\
\text { Disagree }\end{array}$ & Disagree & Neutral & Agree & $\begin{array}{l}\text { Strongly } \\
\text { Agree }\end{array}$ \\
\hline $\begin{array}{l}\text { There is a positive influence of collaborative teaching on } \\
\text { student's performance }\end{array}$ & $5(1.2)$ & $39(9.2)$ & $124(29.2)$ & $171(40.3)$ & $85(20.0)$ \\
$\begin{array}{l}\text { Teachers routinely use collaborative teaching techniques } \\
\text { Group discussions and activities help in fostering students' }\end{array}$ & $6(1.4)$ & $45(10.6)$ & $123(29.0)$ & $168(39.6)$ & $82(19.3)$ \\
& & $43(10.1)$ & $126(29.7)$ & $160(37.7)$ & $88(20.8)$ \\
communication & & & & \\
Interacting in groups help producing fluent and accurate & $5(1.2)$ & $42(9.9)$ & $123(29.0)$ & $164(38.7)$ & $90(21.2)$ \\
utterances & & & & & \\
$\begin{array}{l}\text { Course books provide enough material for group and pair } \\
\text { work }\end{array}$ & $8(1.9)$ & $49(11.6)$ & $127(30.0)$ & $164(38.7)$ & $76(17.9)$ \\
I enjoy working and learning in groups & $4(0.9)$ & $38(9.0)$ & $130(30.7)$ & $175(41.3)$ & $77(18.2)$ \\
I like teacher to explain everything & $2(0.5)$ & $41(9.7)$ & $122(28.8)$ & $177(41.7)$ & $82(19.3)$ \\
I like to learn conversation & $4(0.9)$ & $43(10.1)$ & $130(30.7)$ & $180(42.5)$ & $67(15.8)$ \\
I like to prefer talking in English & $6(1.4)$ & $42(9.9)$ & $123(29.0)$ & $161(38.0)$ & $92(21.7)$ \\
I like that teachers give problems to work on & $6(1.4)$ & $48(11.3)$ & $121(28.5)$ & $166(39.2)$ & $83(19.6)$ \\
Teachers use modern and progressive methods to teach & $6(1.4)$ & $49(11.6)$ & $116(27.4)$ & $171(40.3)$ & $82(19.3)$
\end{tabular}

English

Table 5. ELLs Perception on Group Activities

\begin{tabular}{llllll}
\hline & $\begin{array}{l}\text { Strongly } \\
\text { Disagree }\end{array}$ & Disagree & Neutral & Agree & $\begin{array}{l}\text { Strongly } \\
\text { Agree }\end{array}$ \\
\hline $\begin{array}{l}\text { I prefer group work than other types of } \\
\text { assessment }\end{array}$ & $6(1.4)$ & $46(10.8)$ & $122(28.8)$ & $165(38.9)$ & $85(20.0)$ \\
It motivates me to learn from work & $6(1.4)$ & $35(8.3)$ & $130(30.7)$ & $178(42.0)$ & $75(17.7)$ \\
$\begin{array}{l}\text { It develops my independent learning habit } \\
\text { It helps me develop thinking ability and }\end{array}$ & $6(1.4)$ & $37(8.7)$ & $129(30.4)$ & $169(39.9)$ & $83(19.6)$ \\
self-expression & & $36(8.5)$ & $108(25.5)$ & $166(39.2)$ & $109(25.7)$ \\
It gives me chance to share ideas with others & $3(0.7)$ & $42(9.9)$ & $114(26.9)$ & $187(44.1)$ & $78(18.4)$ \\
I learn better from group interaction than lecture & $2(0.5)$ & $37(8.7)$ & $136(32.1)$ & $169(39.9)$ & $80(18.9)$ \\
A group grade is not fair & $3(0.7)$ & $42(9.9)$ & $112(26.4)$ & $181(42.7)$ & $86(20.3)$ \\
Group assignment makes me unnecessary busy & $6(1.4)$ & $43(10.1)$ & $116(27.4)$ & $162(38.2)$ & $97(22.9)$ \\
It adds burden work on me & $10(2.4)$ & $43(10.1)$ & $121(28.5)$ & $160(37.7)$ & $90(21.2)$ \\
It is difficult to get together outside class & $7(1.7)$ & $38(9.0)$ & $133(31.4)$ & $162(38.2)$ & $84(19.8)$ \\
It is difficult to get relevant references & $4(0.9)$ & $38(9.0)$ & $141(33.3)$ & $159(37.5)$ & $82(19.3)$ \\
It is difficult to share members work equally & $5(1.2)$ & $38(9.0)$ & $123(29.0)$ & $174(41.0)$ & $84(19.8)$ \\
\hline
\end{tabular}

Independent T-test was applied to determine the differences between group activities and collaborative teaching based on the perception of ELLs (Table 6). According to the findings, there was a significant difference in the perception of both male and female ELLs when working with collaborative teaching techniques $(\mathrm{p}<0.05)$, but no difference was found with respect to learning in group activities $(\mathrm{p}>0.05)$. One-Way ANOVA test was applied to determine the differences between collaborative teaching and group activities based on ELLs' grades. 
Opposite results were obtained because students studying in different grades preferred group activities over collaborative teaching methods (Table 7).

Table 6. Independent T-test for Group Activities and Collaborative Teaching based on Gender

\begin{tabular}{lllll}
\hline \multirow{3}{*}{ Group Activities } & Gender & Mean & Std. Deviation & p-value \\
\cline { 2 - 5 } Collaborative Teaching & Male & 3.69 & .286 & 0.459 \\
& Female & 3.67 & .255 & \\
& Male & 3.68 & .275 & 0.022 \\
& Female & 3.61 & .285 &
\end{tabular}

Table 7. One-Way ANOVA for determining difference between Collaborative Teaching and Group Activities based on Grades

\begin{tabular}{lllllll}
\hline & & Sum of Squares & df & Mean Square & F & Sig. \\
\hline Collaborative Teaching & Between Grades & .244 & 2 & .122 & 1.544 & .215 \\
& Within Grades & 33.214 & 421 & .079 & & \\
Troup Activities & Total & 33.458 & 423 & & & \\
& Between Grades & .524 & 2 & .262 & 3.524 & .030 \\
& Within Grades & 31.330 & 421 & .074 & & \\
& Total & 31.854 & 423 & & & \\
\hline
\end{tabular}

\section{Discussion}

The evaluation of collaborative learning reflects that students were aware of the fact that complex problem can be conveniently solved in group activities rather than via individual tasks. Group activities enabled students to learn collaboration and highlight positive and negative aspects of fellows. Besides, most of the students showed satisfaction towards group coaching and peer review. The collaboration and group activities enable students to function collectively for problem solving. In a peer activity, teachers are enabled to closely evaluate and observe their students' needs and identify their weak areas. Teacher's contribution in group activities enables students to enhance their social skills, communication power and critical thinking ability.

Findings of the study elaborate that majority of the students prefer group activities; however, there are also a number of students who do not prefer peer activities. These findings are consistent with the study of Çokparlamış (2010). It is obligatory for teachers to identify the specific learning requirements of each student and apply teaching and learning strategies and activities accordingly. Furthermore, they should identify the reasons that generate unfavorable attitude of students. There are multiple reasons of student's negative attitude towards group activities; it can be mainly due to the nature of the task. For instance, grammar-focused tasks were preferred to be conducted on individual or couple basis; however, the target language communication activities were desired by students to be done in group. As mentioned in the study of Mishra and Oliver (1998), students preferred group activities, but grammar-activities were preferred to be performed individually. According to Storch (2005), the level of accuracy was compromised in group grammar-based activities in comparison with individual basis.

It is reflected from the results that English language teachers do not initiate peer activities in classroom or they find it difficult to instruct and implement it on the groups. The English teachers do not prefer group activities as an effective teaching strategy. Similar findings were reflected in the study of Macquarrie, Howe and Boyle (2012) and Kocaman's (2005), which emphasized that group activities were considered to be an adequate strategy. It was clearly elaborated that implementing a group activity is considered effective by teachers; however, the difficulties may arise due to the lack of necessary set of skill and strategies required for implementing group activities in class (Doymuş \& Koç, 2012; Kocaman, 2005). The review of literature elaborates similar findings about collaborative learning that it is not considered to be effective and efficient enough and is, therefore, used by a niche audience (Antil Jenkins et al., 2003; Baines et al., 2003; Gillies, 2003; Wigglesworth \& Storch, 2012). The further illustration of the results reflects that group activities in lower grades are preferred by English teachers. According to the study of Race and Powell (2000), teachers prefer collaborative learning in lower grades in comparison with higher grades; however, the issue related to younger grade students' efficiency in group activity is a topic of future discussion. It was identified by Gagne and Parks (2013) that during the collaborative learning activity in ESL classroom, elementary-school students were proficient enough to 
strengthen their groups. With respect to learners' perspective, majority of the learners preferred group activities as it was considered to be a motivating factor.

The implementation of collaborative teaching encompasses multiple elements, making students responsible towards their learning and development is also an important part. According to Sarobol (2012), if one member of the group fails to fulfill his/her responsibilities, the burden is then shifted on other group members and this can create disrupting environment and frustrating attitudes. The latest impact of globalization leads to enhanced practice of teaching different foreign languages to students at early stages of school not only in Saudi Arabia but all over the world. Therefore, interpersonal skills of learners should be enhanced by the teachers to increase the effective and efficient peer collaboration.

In future studies, the credibility of questionnaire should be cross-checked by applying regression test. For the confirmation of this claim future studies should include detailed descriptive approach and observation. Such study will highlight the methods of applying collaborative strategies in the context of EFL and identify the effective implementation of these activities.

\section{Conclusion}

The education programs that are designed specifically for the teachers of ELLs should include concept of collaborative learning as a compulsory element. The course program of ELLs teaching shall be enhanced by amalgamating the element of field experience in the course and strengthening the inter-relationship between teachers and other department of the college. Teachers with research and innovative syllabus making skills should be recruited for ELLs' teaching program. This will aid in enhancing practical outcomes of curriculum and expanding the language curriculum. For enhancing the language learning skills in students, teachers must include different group activities as a part of the language curriculum.

\section{Acknowledgement}

The author acknowledges all the associated personnel who contributed in the completion of this study. This study is self-funded. No potential competing interest was reported by the authors.

\section{References}

Anggraini, R., Rozimela, Y., \& Anwar, D. (2020). The Effects of Collaborative Writing on EFL Learners' Writing Skills and Their Perception of the Strategy. Journal of Language Teaching and Research, 11(2), 335-341. https://doi.org/10.17507/jltr.1102.25

Ansari, J. A. N., \& Khan, N. A. (2020). Exploring the role of social media in collaborative learning the new domain of learning. Smart Learning Environments, 7(1), 1-16. https://doi.org/10.1186/s40561-020-00118-7

Babiker, A. (2018). Improving Speaking Skills in EFL Classes through Collaborative Learning. American Scientific Research Journal for Engineering, Technology, and Sciences (ASRJETS), 44(1), 137-154.

Bailey, D., Almusharraf, N., \& Hatcher, R. (2020). Finding satisfaction: intrinsic motivation for synchronous and asynchronous communication in the online language learning context. Education and Information Technologies, 1-21. https://doi.org/10.1007/s10639-020-10369-z

Batd, V. (2013). The effect of using enjoyable cooperative learning supported educational activities on students' self-efficacy skills, self-regulation strategies, metacognitive strategies, motivation and academic achievement in English language teaching [Doctoral dissertation] Frrat University, Elazığ).

Bennett, B. B., Rolheiser-Bennett, N. C., \& Stevahn, L. (1991). Cooperative learning: Where heart meets mind: An interactive resource book. Toronto: Educational Connections.

Bertucci, A., Johnson, D. W., Johnson, R. T., \& Conte, S. (2012). Influence of group processing on achievement and perception of social and academic support in elementary inexperienced cooperative learning groups. The Journal of Educational Research, 105(5), 329-335. https://doi.org/10.1080/00220671.2011.627396

Blatchford, P., Galton, M., Kutnick, P., \& Baines, E. (2005). Improving the effectiveness of pupil groups in classrooms. Final report to ESRC (L139 25 1046).

Blatchford, P., Kutnick, P., Baines, E., \& Galton, M. (2003). Toward a social pedagogy of classroom group work. International Journal of Educational Research, 39(1-2), 153-172. https://doi.org/10.1016/S0883-0355(03)00078-8

Carstensen, S. S., Kjaer, C., Möller, S., \& Bloksgaard, M. (2020). Implementing collaborative, active learning using peer instructions in pharmacology teaching increases students' learning and thereby exam performance. European Journal of Pharmacology, 867, 172792. https://doi.org/10.1016/j.ejphar.2019.172792 
Chen, W., \& Yu, S. (2019). Implementing collaborative writing in teacher-centered classroom contexts: student beliefs and perceptions. Language Awareness, 28(4), 247-267. https://doi.org/10.1080/09658416.2019.1675680

Chen, Y. (2018). Perceptions of EFL College Students toward Collaborative Learning. English Language Teaching, 11(2), 1-4. https://doi.org/10.5539/elt.v11n2p1

Cheong, D. (2010). The effects of practice teaching sessions in second life on the change in pre-service teachers' teaching efficacy. Computers \& Education, 55(2), 868-880. https://doi.org/10.1016/j.compedu.2010.03.018

Çokparlamiş, A. (2010). Effects of cooperative learning on teaching English to young learners.

Daba, T. M., Ejersa, S. J., \& Aliyi, S. (2017). Student Perception on Group Work and Group Assignments in Classroom Teaching: The Case of Bule Hora University Second Year Biology Students, South Ethiopia--An Action Research. Educational Research and Reviews, 12(17), 860-866. https://doi.org/10.5897/ERR2016.3006

Doymuş, K., \& Koç, Y. (2012). Application in the classroom of cooperative learning model of science and technology teachers. Dicle University Journal of Ziya Gökalp Education Faculty, 19, 174-183.

Ebru, K. O. Ç. (2018). Exploring Collaborative Learning with a Focus on Group Activities in EFL Classrooms. Journal of the Faculty of Education, 19(3), 582-597. https://doi.org/10.17679/inuefd.385741

Gagné, N., \& Parks, S. (2013). Cooperative learning tasks in a Grade 6 intensive ESL class: Role of scaffolding. Language teaching research, 17(2), 188-209. https://doi.org/10.1177/1362168812460818

Gillies, R. M. (2003). Structuring cooperative group work in classrooms. International Journal of Educational Research, 39(1-2), 35-49. https://doi.org/10.1016/s0883-0355(03)00072-7

Gillies, R. M. (2007). Cooperative learning: Integrating theory and practice. Sage. https://doi.org/10.4135/9781483329598

Gillies, R. M., \& Ashman, A. F. (1996). Teaching collaborative skills to primary school children in classroom-based work groups. Learning and instruction, 6(3), 187-200. https://doi.org/10.1016/0959-4752(96)00002-3

Gillies, R. M., \& Boyle, M. (2010). Teachers' reflections on cooperative learning: Issues of implementation. Teaching and teacher Education, 26(4), 933-940. https://doi.org/10.1016/j.tate.2009.10.034

Gillies, R. M., \& Boyle, M. (2011). Teachers' reflections of cooperative learning (CL): a two-year follow-up. Teaching Education, 22(1), 63-78. https://doi.org/10.1080/10476210.2010.538045

Harper, J. S., Lamb, S. W., \& Buffington, J. R. (2019). Effective use of case studies in the MIS capstone course through semi-formal collaborative teaching. Journal of Information Systems Education, 19(4), 6.

Hendy, E. (2020). Effects of Instructional Conversations on English Language Learners. Georgia Educational Researcher, 17(2). https://doi.org/10.20429/ger.2020.170205

Jenkins, J. R., Antil, L. R., Wayne, S. K., \& Vadasy, P. F. (2003). How cooperative learning works for special education and remedial students. Exceptional children, 69(3), 279-292. https://doi.org/10.1177/001440290306900302

Johnson, D. W., \& Johnson, R. T. (1990). Using cooperative learning in math. In N. Davidson (Ed.), Cooperative learning in mathematics: A handbook for teachers (pp. 103-125).

Kagan, D. M. (1990). Ways of evaluating teacher cognition: Inferences concerning the Goldilocks principle. Review of educational research, 60(3), 419-469. https://doi.org/10.3102/00346543060003419

Kamala, R., \& Aziz, A. A. (2020). Systematic Review: The Use of Collaborative Learning to Develop Students' Guided Writing and Oral Performance in Poetry. International Journal of Academic Research in Progressive Education and Development, 9(2), 544-573. https://doi.org/10.6007/IJARPED/v9-i2/7663

Kartal, E. E., Cobern, W. W., Dogan, N., Irez, S., Cakmakci, G., \& Yalaki, Y. (2018). Improving science teachers' nature of science views through an innovative continuing professional development program. International Journal of STEM Education, 5(1), 30. https://doi.org/10.1186/s40594-018-0125-4

Kocaman, S. (2005). Investigations on the triangulation accuracy of Starimager imagery. Geospatial goes global. 
Krammer, M., Rossmann, P., Gastager, A., \& Gasteiger-Klicpera, B. (2018). Ways of composing teaching teams and their impact on teachers' perceptions about collaboration. European journal of teacher education, 41(4), 463-478. https://doi.org/10.1080/02619768.2018.1462331

Law, Q., Chung, J., Leung, L., \& Wong, T. (2017). Perceptions of collaborative learning in enhancing undergraduate education students' engagement in teaching and learning English. US-China Education Review, 7(2), 89-100. https://doi.org/10.17265/2161-623X/2017.02.002

Le, H., Janssen, J., \& Wubbels, T. (2018). Collaborative learning practices: teacher and student perceived obstacles to effective student collaboration. Cambridge Journal of Education, 48(1), 103-122. https://doi.org/10.1080/0305764X.2016.1259389

Lee, J. (2014). Using Group-Work to Optimize Learning Opportunities for Grade 1 and 2 English Language Learners in the Classroom. [Degree of Master of Teaching] University of Toronto.

Lee, J. H., \& Macaro, E. (2013). Investigating age in the use of L1 or English-only instruction: Vocabulary acquisition by Korean EFL learners. The Modern Language Journal, 97(4), 887-901. https://doi.org/10.1111/j.1540-4781.2013.12044.X

Lopata, C., Miller, K. A., \& Miller, R. H. (2003). Survey of actual and preferred use of cooperative learning among exemplar teachers. The journal of educational research, 96(4), 232-239. https://doi.org/10.1080/00220670309598812

MacQuarrie, S., Howe, C., \& Boyle, J. (2012). Exploring the characteristics of small groups within science and English secondary classrooms. Cambridge Journal of Education, 42(4), 527-546. https://doi.org/10.1080/0305764X.2012.733345

Marks, M. B., \& O’Connor, A. H. (2013). Understanding students' attitudes about group work: What does this suggest for instructors of business? Journal of Education for Business, 88(3), 147-158. https://doi.org/10.1080/08832323.2012.664579

Mishra, S., \& Oliver, R. (1998). Secondary school ESL learners' perceptions of pair work in Australian classrooms. TESOL in Context, 8(2), 19.

Muijs, D., \& Reynolds, D. (2005). Effective teaching: Introduction \& conclusion.

Murdoch, N. L., Epp, S., \& Vinek, J. (2017). Teaching and learning activities to educate nursing students for interprofessional collaboration: a scoping review. Journal of interprofessional care, 31(6), 744-753. https://doi.org/10.1080/13561820.2017.1356807

Namaziandost, E., \& Çakmak, F. (2020). An account of EFL learners' self-efficacy and gender in the Flipped Classroom Model. Education and Information Technologies, 1-15. https://doi.org/10.1007/s10639-020-10167-7

Novitasari, A., Raja, P., \& Flora, F. (2018). Designing collaborative blended learning activities to improve students' argumentative essay writing ability and students' perception. U-JET, 7(4). https://doi.org/10.23960/jpp

Novitasari, N. F. (2019). Collaborative learning in ESP speaking classroom: learners' perceptions and experiences. KnE Social Sciences, 309-319. https://doi.org/10.18502/kss.v3i10.3912

Park, J. H., \& Ham, S. H. (2016). Whose perception of principal instructional leadership? Principal-teacher perceptual (dis) agreement and its influence on teacher collaboration. Asia Pacific Journal of Education, 36(3), 450-469. https://doi.org/10.1080/02188791.2014.961895

Pathak, A., \& Intratat, C. (2016). Use of semi-structured interviews to investigate teacher perceptions of student collaboration. Malaysian Journal of ELT Research, 8(1), 10.

Poupore, G. (2016). Measuring group work dynamics and its relation with L2 learners' task motivation and language production. Language Teaching Research, 20(6), 719-740. https://doi.org/10.1177/1362168815606162

Poupore, G. (2018). A complex systems investigation of group work dynamics in L2 interactive tasks. The Modern Language Journal, 102(2), 350-370. https://doi.org/10.1111/modl.12467

Race, K. E., \& Powell, K. R. (2000). Assessing student perceptions of classroom methods and activities in the context of an outcomes-based evaluation. Evaluation Review, 24(6), 635-646. https://doi.org/10.1177/0193841X0002400604 
Rao, P. S. (2019). Collaborative learning in English language classrooms. ACADEMICIA: An International Multidisciplinary Research Journal, 9(2), 5-16. https://doi.org/10.5958/2249-7137.2019.00020.x

Sarobol, N. (2012). Implementing Cooperative Learning in English Language Classroom: Thai University Students' Perceptions. International Journal of Interdisciplinary Social Sciences, 6(10), 111-122. https://doi.org/10.18848/1833-1882/CGP/v06i10/52170

Schwartz, S., \& Pollishuke, M. (2012). Creating the dynamic classroom: A handbook for teachers. Pearson Education Canada.

Stead, L. A. (2018). Supporting English Language Learners through Collaboration, Compassion, and Engagement. [Master's Thesis]. Utah State University.

Storch, N. (2005). Collaborative writing: Product, process, and students' reflections. Journal of second language writing, 14(3), 153-173. https://doi.org/10.1016/j.jslw.2005.05.002

Su, Y., Li, Y., Hu, H., \& Rosé, C. P. (2018). Exploring college English language learners' self and social regulation of learning during wiki-supported collaborative reading activities. International Journal of Computer-Supported Collaborative Learning, 13(1), 35-60. https://doi.org/10.1007/s11412-018-9269-y

Such, B. (2019). Scaffolding English language learners for online collaborative writing activities. Interactive Learning Environments, 1-9. https://doi.org/10.1080/10494820.2019.1579233

Takeuchi, M. A. (2016). Friendships and group work in linguistically diverse mathematics classrooms: Opportunities to learn for English language learners. Journal of the Learning Sciences, 25(3), 411-437. https://doi.org/10.1080/10508406.2016.1169422

Tao, P. K., \& Gunstone, R. F. (1999). Conceptual change in science through collaborative learning at the computer. International Journal of Science Education, 21(1), 39-57. https://doi.org/10.1080/095006999290822

Tian, L., \& Macaro, E. (2012). Comparing the effect of teacher codeswitching with English-only explanations on the vocabulary acquisition of Chinese university students: A lexical focus-on-form study. Language Teaching Research, 16(3), 367-391. https://doi.org/10.1177/1362168812436909

Tonbul, Y. (2006). Opinions about the Effectiveness of "Vocational Work" Practices in Primary Schools. Turkish Journal of Educational Sciences, 4(1), 13-30.

Vygotsky, L. (1978). Interaction between learning and development. Readings on the development of children, 23(3), 34-41. https://doi.org/10.2307/j.ctvjf9vz4.11

Wigglesworth, G., \& Storch, N. (2012). What role for collaboration in writing and writing feedback? Journal of Second Language Writing, 21(4), 364-374. https://doi.org/10.1016/j.jslw.2012.09.005

Woolfolk, A. E. (1998). Helping students to be strategic learners. Educational Psychology. 2nd ed. New York: Allyn \& Bron Co, 271.

\section{Copyrights}

Copyright for this article is retained by the author(s), with first publication rights granted to the journal.

This is an open-access article distributed under the terms and conditions of the Creative Commons Attribution license (http://creativecommons.org/licenses/by/4.0/). 